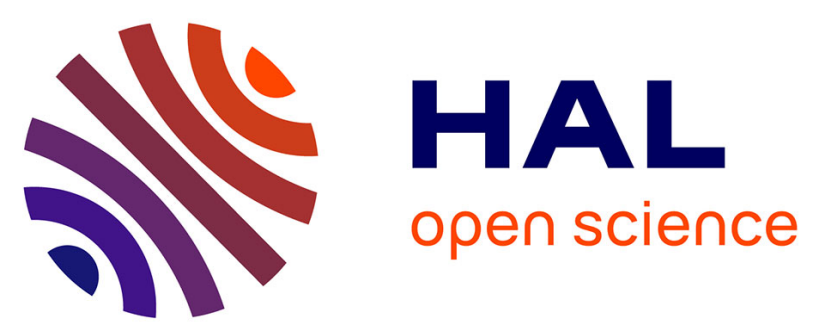

\title{
The effects of four crop protection products on the morphology and ultrastructure of the hypopharyngeal gland of the European honeybee, Apis mellifera
}

Kevin Heylen, Bruno Gobin, Lutgarde Arckens, Roger Huybrechts, Johan Billen

\section{To cite this version:}

Kevin Heylen, Bruno Gobin, Lutgarde Arckens, Roger Huybrechts, Johan Billen. The effects of four crop protection products on the morphology and ultrastructure of the hypopharyngeal gland of the European honeybee, Apis mellifera. Apidologie, 2011, 42 (1), pp.103-116. 10.1051/apido/2010043 . hal-01003577

\section{HAL Id: hal-01003577 https://hal.science/hal-01003577}

Submitted on 1 Jan 2011

HAL is a multi-disciplinary open access archive for the deposit and dissemination of scientific research documents, whether they are published or not. The documents may come from teaching and research institutions in France or abroad, or from public or private research centers.
L'archive ouverte pluridisciplinaire HAL, est destinée au dépôt et à la diffusion de documents scientifiques de niveau recherche, publiés ou non, émanant des établissements d'enseignement et de recherche français ou étrangers, des laboratoires publics ou privés. 


\title{
The effects of four crop protection products on the morphology and ultrastructure of the hypopharyngeal gland of the European honeybee, Apis mellifera*
}

\author{
Kevin HeYlen ${ }^{1,2,3}$, Bruno GobIN ${ }^{4,5}$, Lutgarde ARCKENs ${ }^{1}$, Roger HuYBRECHTS ${ }^{3}$, \\ Johan BILLEN ${ }^{2}$ \\ ${ }^{1}$ Laboratory of Neuroplasticity and Neuroproteomics, Katholieke Universiteit Leuven, Naamsestraat 59, \\ 3000 Leuven, Belgium \\ ${ }^{2}$ Laboratory of Entomology, Katholieke Universiteit Leuven, Naamsestraat 59, 3000 Leuven, Belgium \\ ${ }^{3}$ Laboratory of Insect Physiology and Molecular Ethology, Katholieke Universiteit Leuven, Naamsestraat 59, \\ 3000 Leuven, Belgium \\ ${ }^{4}$ Zoology Department PcFruit, Fruitteenweg 1, 3800 Sint-Truiden, Belgium \\ ${ }^{5}$ Research Centre for Ornamental Plants, Schaessestraat 18, 9070 Destelbergen, Belgium
}

Received 17 June 2009 - Revised 25 January 2010 - Accepted 8 February 2010

\begin{abstract}
This study describes the impact of sublethal doses of 4 pesticides on size and morphology of the honeybee worker's hypopharyngeal glands. This gland plays an essential role in brood care by young workers, and thus colony growth. Contaminating 7 day old caged bees, we sampled after 1 day and 1 week for Captan-, Imidacloprid- and Indoxacarb-treated bees and after 1, 2, 3, 4, 5 and 7 days for Fenoxycarb-treated bees. The glands' acini 1 week post-treatment were all significantly smaller in treated bees. However, lightand electron microscopy showed hardly any difference between controls and gland cells, treated with Captan, Imidacloprid or Indoxacarb. Yet upon Fenoxycarb-treatment, acini showed a decrease in size, a granular texture and unorganized cytoplasm more quickly than normal. Indeed, after only 7 days, Fenoxycarb-treated glands displayed features typical of the onset of foraging in older bees.
\end{abstract}

crop protection products / hypopharyngeal gland / honeybee / histology

\section{INTRODUCTION}

Bee pollination is essential for the production of a variety of agricultural crops, especially in the fruit growing industry. However, there is a substantial environmental impact on honeybees. Exposure to external factors can have direct effects on individual bees as well as indirect effects on entire colonies. The honeybee society depends on extreme task specialization, fine tuned to the needs of the colony.

Corresponding author: J.Billen, johan.billen@bio.kuleuven.be * Manuscript editor: Monique Gauthier
Crop protection products, necessary to protect plants during the pre-flowering and flowering period, pose a potential risk in changing honeybee demography by inducing behavioral changes, thereby modifying this task distribution. Several behavioral studies, dealing with sublethal effects of pesticides, have indicated that there might be an important impact of such products on winter mortality (Faucon et al., 2002; Thompson et al., 2007), orientation (Decourtye et al., 2004), homing behavior (Bortolotti et al., 2003), locomotor activity (Suchail et al., 2001; El Hassani et al., 2008) and communicative capacity (Haynes, 1988; Medrzycki et al., 2003). 
In this study we aimed at elucidating the influence of sublethal doses of four products often used in the fruit growing industry, namely Captan, Imidacloprid, Fenoxycarb and Indoxacarb, on the size and morphology of the honeybee's hypopharyngeal glands.

There are several reasons why we chose to investigate these four agents. Captan is a commonly applied fungicide and is used in the production of wheat, corn, cotton, vegetables and fruit trees to control a variety of diseases. It interacts with the fungus' energy household, for example in apple scab (Owens, 1969). Although not insecticidal, the intensive use of Captan might make it a possible stressor for the honeybee. The "Insect Growth Regulator" Fenoxycarb is used to control pest insects attacking vines, cotton and fruit, and is widely used as a juvenile hormone analog affecting important processes like molting, task specialization and reproduction (Thompson et al., 2005). Fenoxycarb was included mainly because it is toxic to a broad spectrum of insects during their embryonic and last larval stages. Fenoxycarb is banned during crop flowering as it is toxic to bee brood although relatively safe for adults (Dhadialla et al., 1998). Imidacloprid, widely reviewed in behavioral papers and considered harmful for bees, is a systemic neonicotenoid insecticide acting on insect neuronal acetylcholine receptors. It thereby interferes with the nervous system's communication (Buckingham et al., 1997; Chauzat et al., 2006). It is used widely against pest insects in corn, wheat, rice, potatoes, citrus and apple trees, with a strict waiting period during and prior to crop flowering. Finally, Indoxacarb, is a non-systemic member of the oxadiazine chemistry and blocks sodium channels in the nervous system of target pests like the vine and fruit moth (Lapied et al., 2001; Tsurubuchi et al., 2003). Indoxacarb is toxic to bees through direct exposure to spray liquid, but not if bees are exposed to dry residue (van der Steen, 2001).

The rationale to test the impact on the honeybee's hypopharyngeal glands is that the secretion of these glands, royal jelly, is the main food source for honeybee larvae and is provided by young worker bees (Hrassnigg and Crailsheim, 1998). A decrease in the activity of the gland and thus in the production of royal jelly would seriously hamper the growth and brood care of the colony. Based on timeseries experiments, we here present morphological and histological data on the effects of these products at several time points during gland development. Since the structure of the hypopharyngeal gland is already known to change as bees grow older, and while also the size of the gland, which is closely related to its activity, has been reported to change over time (Deseyn and Billen, 2005), relevant control bees were included to be able to differentiate age from pesticide effects. Since some studies suggest that certain IGRs like Fenoxycarb can cause underdevelopment of the hypopharyngeal gland (Sasagawa et al., 1989; Tasei, 2001; Malone et al., 2004), we specifically included extra data points on the effects of this important insecticide.

\section{MATERIALS AND METHODS}

\subsection{Hives and experimental design}

For each experiment, matched beehives at a single location were chosen which were of similar size and had similar amounts of brood of the same age. Each hive contained about 18000 bees on 10 frames $(40 \times 20 \mathrm{~cm})$ of which about $1 / 3$ contained open brood. Bee hives were located in a pome fruit growing region adjacent to a mixed forest of 1 ha in the midst of about 25 ha apple and pear orchard, with some cherry trees. Forest edges were sown in with mixed bee flowers to increase pollen availability throughout the season. We used European honeybees, Apis mellifera, of the carnica strain.

Six experiments were set up during two consecutive summers; 3 in the first year and 3 in the next year. Control bees, receiving a sugarwater only placebo treatment, or bees treated with one of the four pesticides (fed in sugarwater solution in a worst case sublethal concentration, 10 times less than the $\mathrm{LD}_{50}$-values: Captan $120 \mathrm{ppm}$, Imidacloprid $1 \mathrm{ppb}$, Fenoxycarb 100 ppm, Indoxacarb 300 ppb), were orally contaminated in a cage-contamination setup. For each replicated trial new solutions were prepared in accordance to ICPBR and EPPO guidelines for efficacy and side-effect testing, from commercial pesticides, thus ensuring that the solution contained the desired concentration. Cage treatments 
were as follows: marked bees of known age were collected from a single colony for a given trial and transferred to cages for treatment. Each cage in a single trial contained the same number of bees, varying between trials from $15-30$, depending on available bees of identical ages. The feeding solution was administered to cages through three eppendorf tubes with drinking holes, and weighted before and after treatment. Treatment lasted $24 \mathrm{~h}$. Since bees readily exchange any ingested food, this ensures an even distribution between tested bees (ICPBR guideline). 10 bees each time were dissected in Ringer-Jolly-solution at 8 and 14 days of adulthood ( 1 day and 1 week post-treatment, respectively). For control and Fenoxycarb-treated colonies only, samples at additional time points (8, $9,10,11,12$ and 14 days of adulthood) were collected a year later from 3 different colonies. Fifteen acini diameter measurements were performed on each gland and five glands per condition were analysed.

\subsection{Sampling}

Synchronizing animals within a time frame of $24 \mathrm{~h}$ was done by paint-marking worker bees the day of their emergence. Contamination was done when the paint-marked bees were 7 days old. Paintmarked bees were randomly sampled early morning (06 h 00-08 h 00) from within the hive. This ensured that most bees were inside the hive, independent of their task.

\subsection{Histology and ultramorphology}

Hypopharyngeal glands were fixed in $2 \%$ glutaraldehyde during 2-20 h $\left(4{ }^{\circ} \mathrm{C}, \mathrm{pH} 7.3\right.$ and buffered with $0.05 \mathrm{M}$ sodium cacodylate). Postfixation in a buffered osmiumtetroxide solution $(1 \mathrm{~h})$ was followed by dehydration in a graded acetone series and embedding in Araldite. Before tissuesections were made, we used the transparant embedding blocks to measure the size of acinar clusters perpendicular to the longer axis of each intact oval acinus under a M-12 Leica binocular microscope, using the Image Analysis v3.2 software program. Semi-thin sections ( $1 \mu \mathrm{m}$ thickness $)$ for light microscopy were made with a Reichert OmU2 ultramicrotome and stained with methylene blue and thionin. Ultra-thin sections, made with a Reichert Ultracut E microtome, were contrasted with uranyl acetate and lead citrate, and examined in a Zeiss EM900 electron microscope.

Statistical analyses were performed using a general linear model full-factorial 2-way ANOVA, with colony set as random factor. Additionally, data from the first year were subsequently subjected to a Tukey HSD post-hoc analysis to examine possible individual significant differences.

\section{RESULTS}

The structure of the hypopharyngeal gland is known to change as bees grow older. Also the size of the gland, which is closely related to its activity, has been reported to change over time. In this study, fifteen acini diameter measurements were performed on each gland and five glands per condition were analysed for 8 and 14 day old control and pesticide-treated workers. As the bees grew older, the acini diameters indeed decreased (Fig. 1, white bars). Moreover, in 14 day old bees the acini of all treated bees were smaller compared to control bees, clearly significant for Imidacloprid and Fenoxycarb, and to a lesser extent for Captan and Indoxacarb. Although we realize that in researching products, already in use in real-life situations, we have to be careful in our conclusions, this seems to indicate a rather general negative effect on gland size and activity for each of the crop protection products one week post-treatment. The significant interaction effect between pesticides and age indicates that the observed decline in acini diameter 1 week after treatment cannot be attributed to age alone (Fig. 1, Tab. I).

Not only the size of the gland but also its structure was used to describe the physiological state of the worker bees. The typical secretory cycle in control bees is known very well. The light-microscopy and electronmicroscopy photographs of 8 and 14 day old bees (Figs. 2 and 3) demonstrate how the structure evolves, not only in glands of control bees but also in those of treated bees. In 8 day control bees we observed a lot of secretory vesicles. This age features a peak moment in the accumulated secretion of the gland cells. Here, the alveolar clusters of cells were the biggest (Fig. 2A). At the ultrastructural level 


\section{HPG acini diameter}

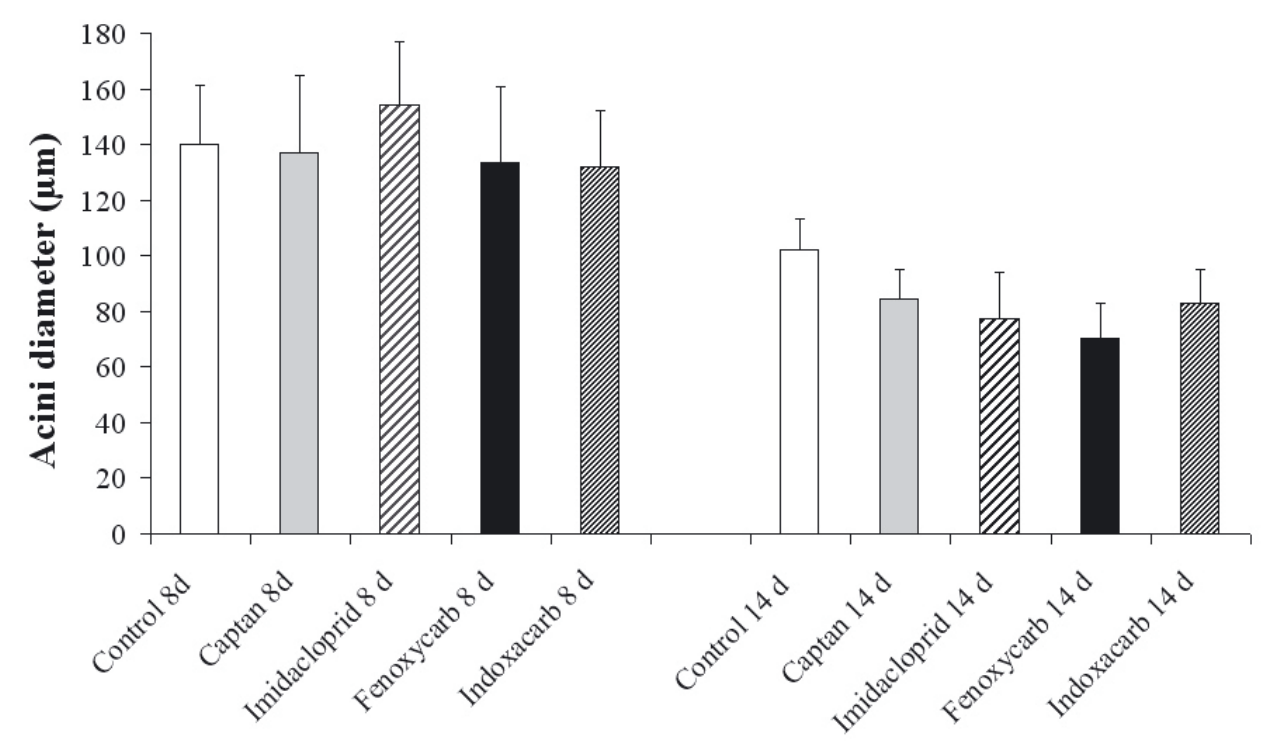

Figure 1. Mean diameter of the acini of the hypopharyngeal gland in function of the age and the condition/treatment of the worker bees. Older bees, as expected, have consistently smaller acini. In 14 day old bees the acini are all smaller in the treated bees compared to the control bees. Error bars represent standard deviation. (see also Tab. I).

we did not only see these vesicles but also a lot of granular endoplasmatic reticulum (RER) forming pack layers, indicative for a high rate of protein synthesis (Figs. 3A, 3B).

In 14 day old controls the acini were smaller and we observed fewer vesicles (Fig. 2F). The nature of the secretion also changed into a more granular appearance at 14 days. Ultrastructurally, less vesicles were present in the now less densely filled cytoplasm. There is however still a lot of ongoing protein synthesis since forager-specific proteins have to be formed, yielding smaller, more electron-dense vesicles (Fig. 3F).

Upon Captan treatment the acini did not differ much from the control ones. Looking at the light-microscopic images at 14 days, both Imidacloprid and Indoxacarb treatments seemed to display a lot more small vesicles than in the control glands but ultrastructural images did not reveal clear changes (Figs. 2H-
$\mathrm{J}$ and $3 \mathrm{H}-\mathrm{J}$ ). For Fenoxycarb, however, the acini showed malformations in size and shape, indicating disintegration early in life (Fig. 2I). Here the glands already had a granular texture at day 8 (occurring in control bees at 14 days) (Figs. 2D, 3D). The cytoplasm appeared unorganized and at day 14 hardly any RER was left (Fig. 3I). Even the appearance of lysozomes, responsible for breaking down the cells, could be observed in 14 day old Fenoxycarb-treated bees (Fig. 3I).

Since Fenoxycarb-treatment exhibited such pronounced effects, glands at additional time points between 8 and 14 days were collected the next year from 3 separate colonies, for which again both size and structure were examined.

Fifteen acini diameter measurements were performed in each gland and five glands per condition were analysed for the time points of $8,9,10,11,12$ and 14 days of adulthood. At 

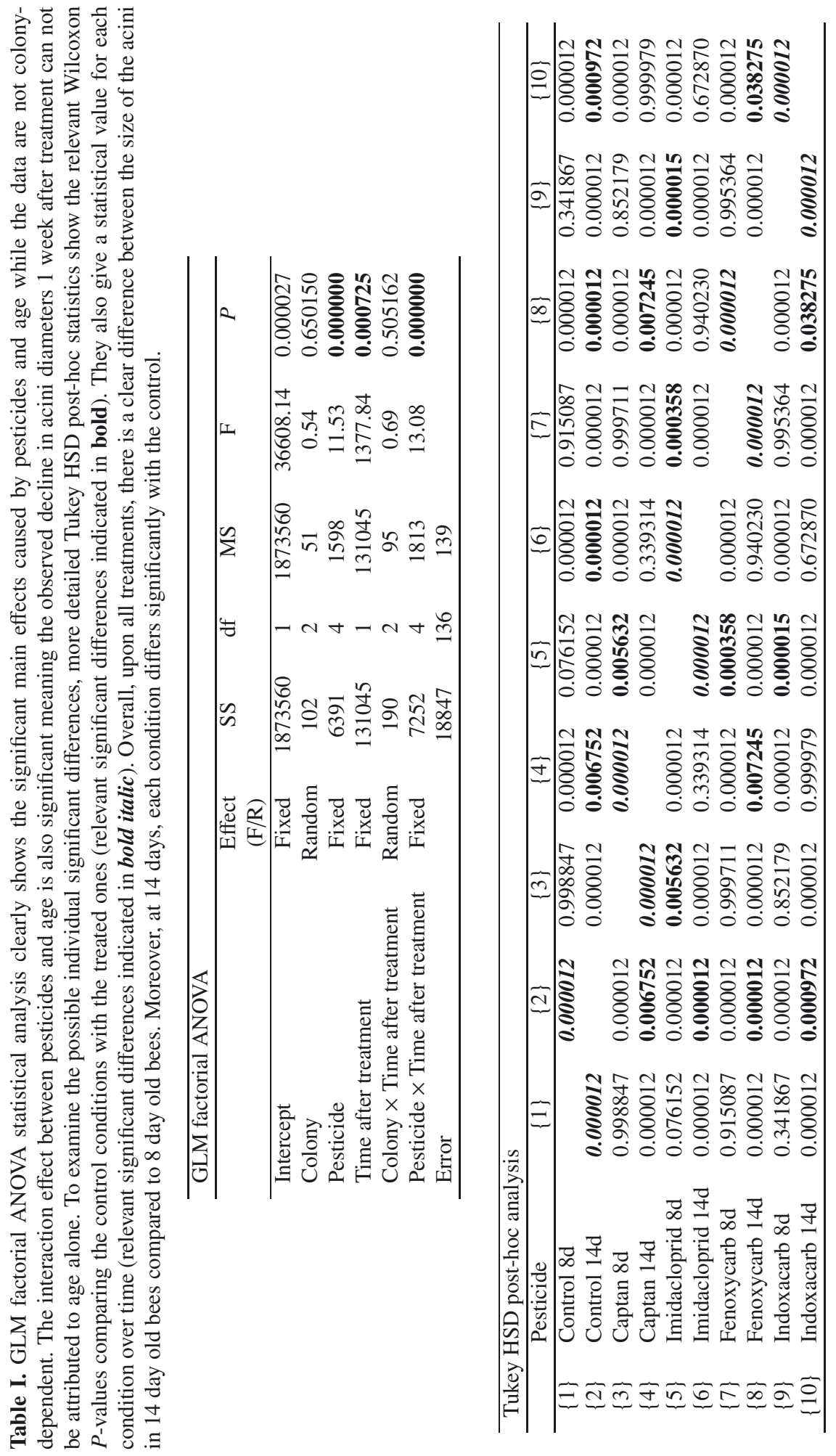

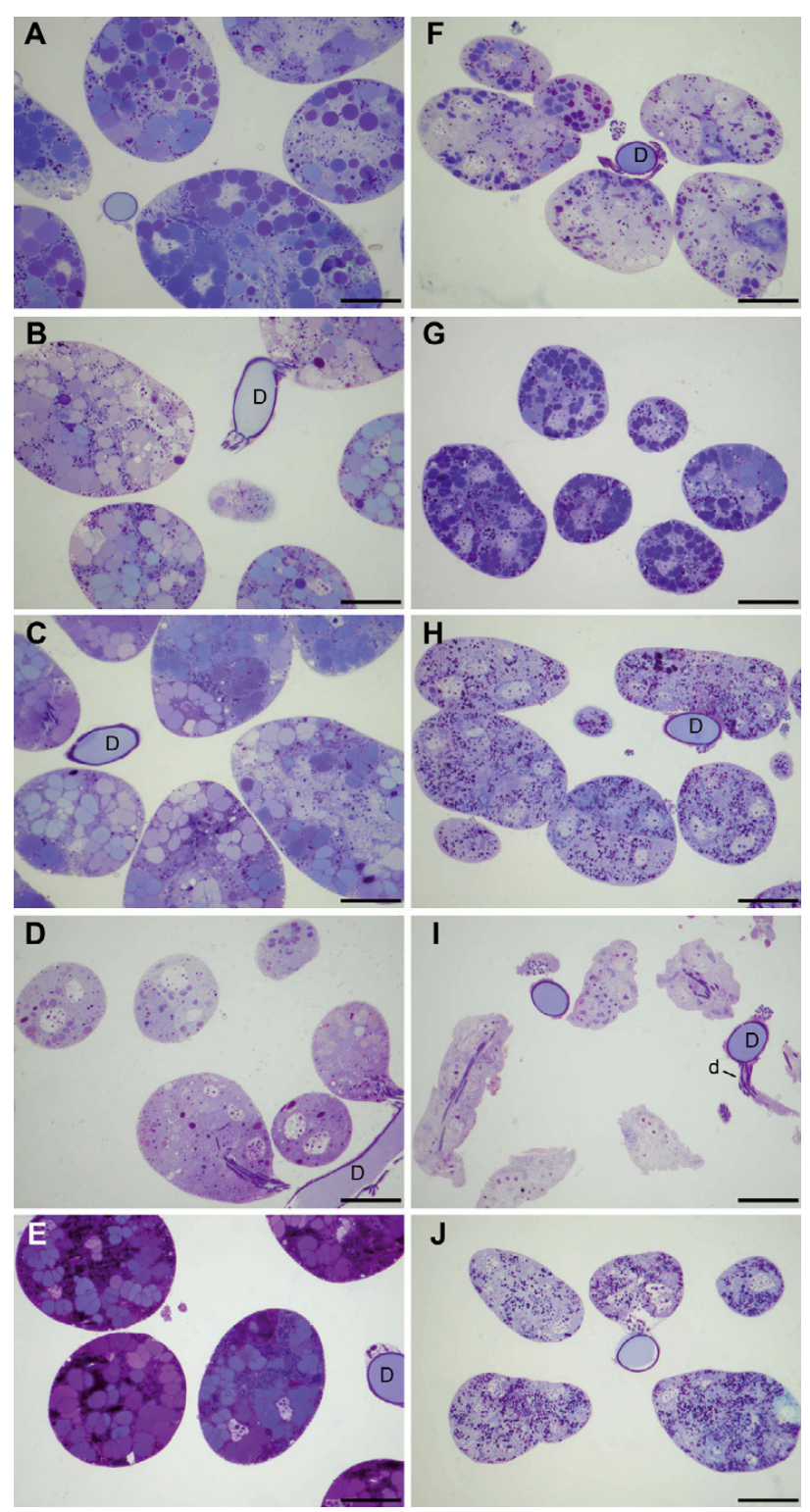

Figure 2. Light-microscopic photographs of hypopharyngeal gland acini (scale bar $50 \mu \mathrm{m})$. Left column: 8 day old bees, right column: 14 day old bees. Each row represents a different condition: Control (A and F), Captan (B and G), Imidacloprid (C and H), Fenoxycarb (D and I) and Indoxacarb (E and J). Normally, acini are round and have a regular shape throughout their development while decreasing in size as the bees age. This can be seen in all conditions except for Fenoxycarb-treated bees where smaller acini (D) and malformations in size and shape occur (I). Typically, the secretory cycle also changes over time in control bees, shifting to smaller, more dense vesicles in older bees $(F)$. The same is true upon application with Captan (G). However, at 14 days, Imidacloprid and Indoxacarb treated bees display a more radical shift by secreting large amounts of granular vesicles $(\mathrm{H}, \mathrm{J})$. This granular state is already visible in 8-day old Fenoxycarb-treated bees (D). The change in these glands in 14 day-old bees is far worse than in any other condition. With hardly any vesicles left secretion comes to a full stop (I). Used symbols: D: main duct; d: duct cell. 

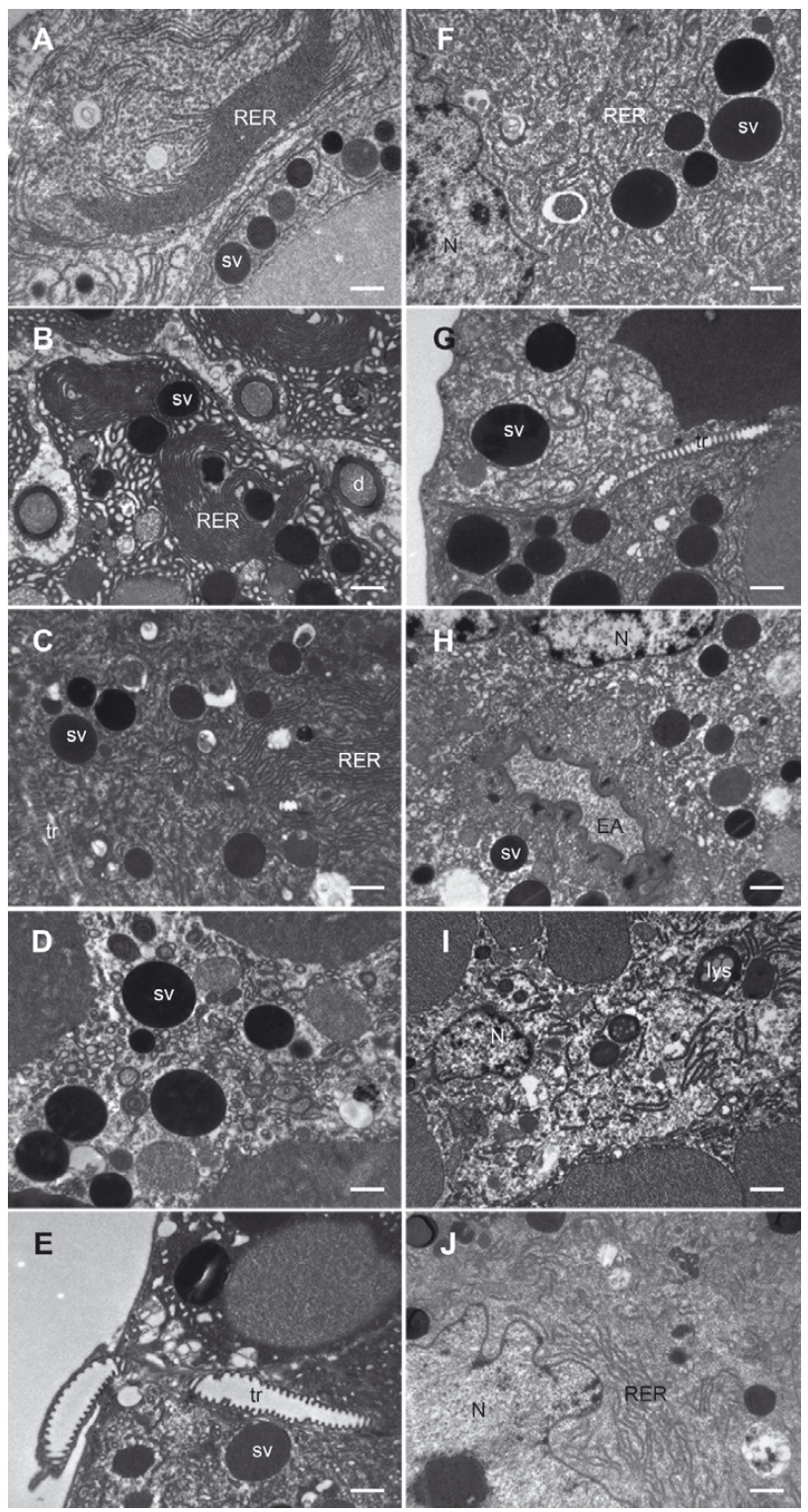

Figure 3. Electron microscopy photographs of hypopharyngeal gland cells (scale bar $1 \mu \mathrm{m}$ ). Left column: 8 day old bees, right column: 14 day old bees. Each row represents a different condition: Control (A and F), Captan (B and G), Imidacloprid (C and H), Fenoxycarb (D and I) and Indoxacarb (E and J). Again, as in Figure 2, the change in the gland's structure clearly reflects the age difference. Typically, day 8 is a peak moment in the secretory cycle. Evidence for this is apparent in control bees and in Captan-, Imidaclopridand Indoxacarb-treated bees which exhibit a large amount of RER and vesicles (A, B, C, E). In gland cells of 14 day-old bees from these conditions, the RER is much less abundant, the vesicles are more electrondense and the cytoplasm is less organized (F, G, H and J). Again, treatment with Fenoxycarb resulted in a seemingly accelerated gland development, showing these electron-dense vesicles already at day 8 (D), with few RER. A week later, no vesicles are present anymore and cells start to degenerate due to the action of lysozomes (I). Used symbols: d: duct cell; EA: end apparatus; lys: lysozome; N: nucleus; RER: granular endoplasmatic reticulum; sv: secretory vesicles; tr: tracheole. 
each timepoint, bees treated with Fenoxycarb had smaller acini than control bees (Fig. 4). This size difference between control and treated bees was practically the same at all time points, except at day 14 , a week after treatment, where the gland's acini were $30 \%$ and $38 \%$ smaller in Fenoxycarb-treated bees, compared to the control condition, in the first and second year respectively. These consequent results of two independent data sets from different years again emphasize the effect Fenoxycarb has on the hypopharyngeal gland. Although the acini in both the control and the Fenoxycarb-treated bees become smaller over time, the decrease in Fenoxycarb-treated animals occurs significantly more quickly. Indeed, the interaction effect between treatment and time is again significant (Tab. II).

Light- and electron-microscopic images of $8,10,12$ and 14 day old gland tissue clearly show the gradual course of the secretory cycle of the gland, both in normal and Fenoxycarbtreated bees (Figs. 5 and 6). As already described, we noticed a lot of secretory vesicles and RER in 8 day control bees (Figs. 5A, 6A). In older control bees (day 10-12) the number of vesicles was already decreased and the acini were smaller here (Figs. 5B, C). The type of the secretion also changed, gradually forming a granular texture at day 12 and 14 (Figs. 5C, D). At the ultrastructural level, less vesicles were observed in the now less densely filled cytoplasm, but they were more electrondense (Figs. 6C, D).

Upon treatment however, the acini quickly showed malformations in size and shape, starting from day 10 onwards, due to the action of degenerative processes (Figs. $5 \mathrm{~F}-\mathrm{H}$ ). As already stated above, treated glands from day 8 already had the same internal structure as glands from 14 day old control bees (Figs. 5E, $6 \mathrm{E})$. The cytoplasm appeared unorganized and a few days later secretion gradually decreased (Figs. 5F, 6F) and there was hardly any RER left. The cells started to merge and lysozomes, responsible for breaking down the cells, appeared (day 12 and 14) (Figs. 5G, H and $6 \mathrm{G}, \mathrm{H})$.

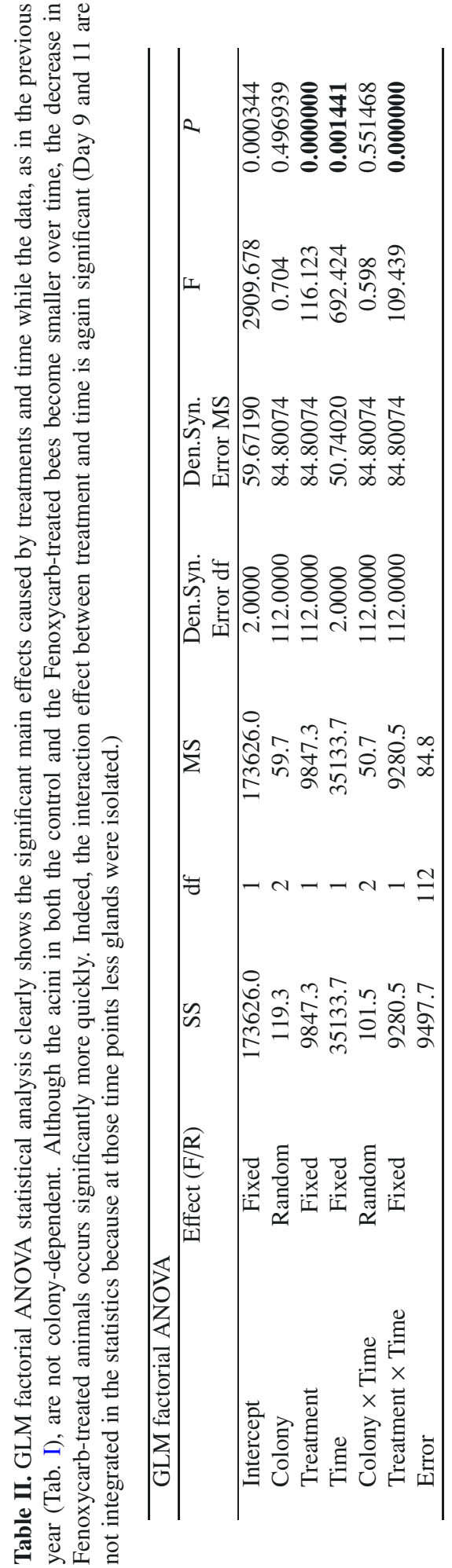




\section{HPG acini diameter}

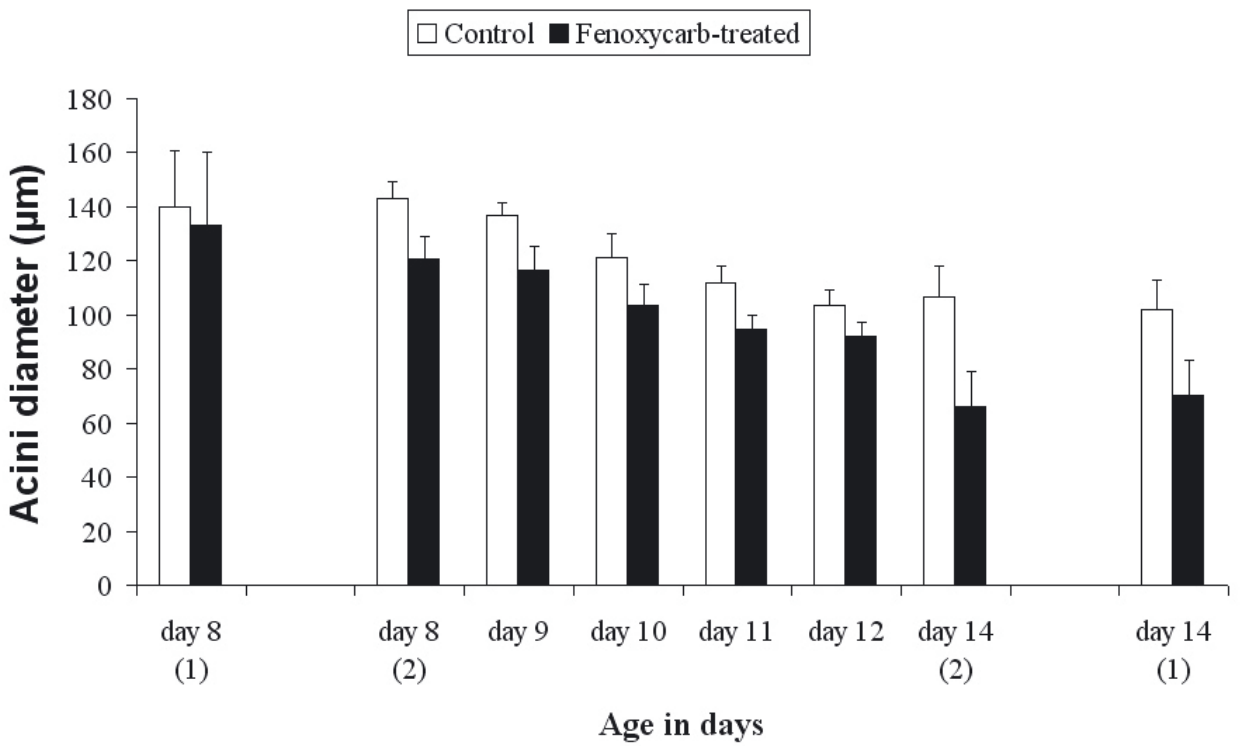

Figure 4. The acini diameters over time in control and Fenoxycarb-treated bees. The outer left and outer right bars represent data from the first year ${ }^{(1)}$, the bars in between represent data from the second year ${ }^{(2)}$. As the bees get older, the acini diameters decrease, as could be expected (Deseyn and Billen, 2005). At each timepoint bees treated with Fenoxycarb had smaller acini than control bees, except at day 8 in the first year. This size difference between control and treated bees was comparable for all time points, except at day 14 where the gland's acini were $30 \%$ and $38 \%$ smaller in Fenoxycarb-treated bees, compared to the control condition, in the first and second year respectively (see also Tab. II). Error bars represent standard deviation.

\section{DISCUSSION}

Notwithstanding the many studies that already described the effects of sublethal doses of crop protection products on a whole range of behavioral traits, this is the first attempt to describe, visualize and quantify the effects of such products on the size and morphology of the developmentally very important hypopharyngeal gland of the honeybee. We anticipated that a clear effect on acini diameter and overall gland histology might reflect the colony fitness.

The size of the gland, reflecting its activity, was measured upon treatment with four different products. Besides age having a predicted effect, the acini in 14 day old bees were all smaller in the treated bees compared to controls. This decrease was significant in
Fenoxycarb-treated bees and this indicates this pesticide displays a negative effect on gland size and activity one week post-treatment. Although the same was true for Captan-, Imidacloprid- and Indoxacarb-treated bees, their histological differences with the controls were too small to draw any conclusions and further research might be necessary. However, for Fenoxycarb-treated bees, analysis of additional time points revealed that only a few days after treatment, at day 12 , the acini started to somehow aggregate, thereby troubling and masking the acini's decreasing size which became clear a week after treatment, in the 14 day old bees. There, the gland cells started to fall apart.

Light- and electron microscopy images show hardly any difference between control gland cells and those of Captan-, 

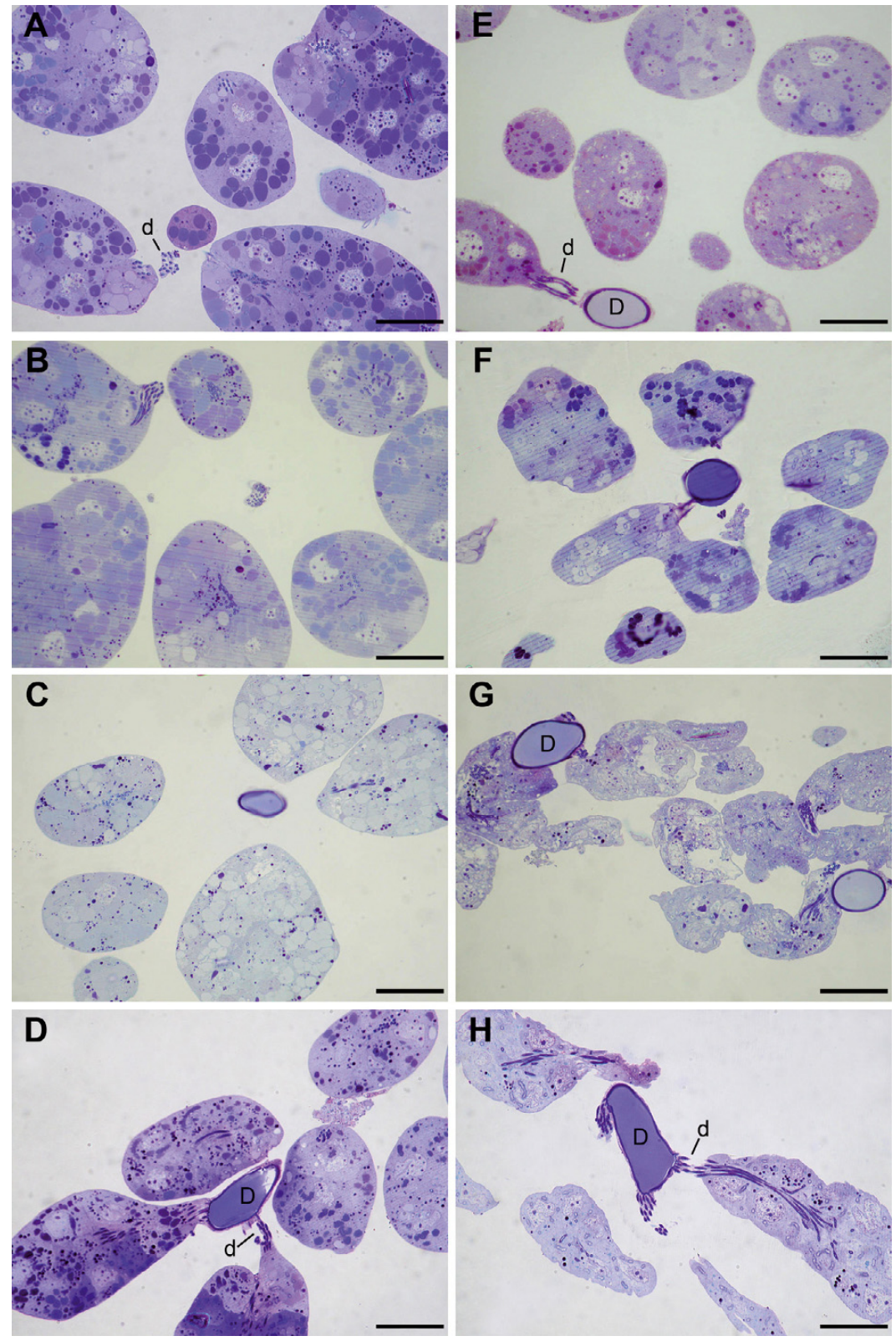

Figure 5. Light-microscopic photographs of hypopharyngeal gland acini (scale bar $50 \mu \mathrm{m}$ ). Left column: glands of control bees in a time series with 8 day (A), 10 day (B), 12 day (C) and 14 day old bees (D). Right column: glands of Fenoxycarb-treated bees, same time series as control from $(\mathrm{E}-\mathrm{H})$. In control bees' glands, acini stay well-shaped and round during development although they decrease in size. Upon treatment, however, the acini quickly show malformations in size and shape, indicating desintegration early in life. Moreover, control bees exhibit a typical secretion pattern and activity over time, secreting plenty large vesicles at day 8 and 10 (A and B), but gradually forming a more granular secretion at day 12 and 14 (C and D). On the other hand, treated glands already have this grainy texture from day 8 (E). A few days later secretion gradually decreases from day $10(\mathrm{~F})$ and the cells start to merge and lyse on days 12 and 14 (G and $\mathrm{H})$. Used symbols: D: main duct; d: duct cell. 

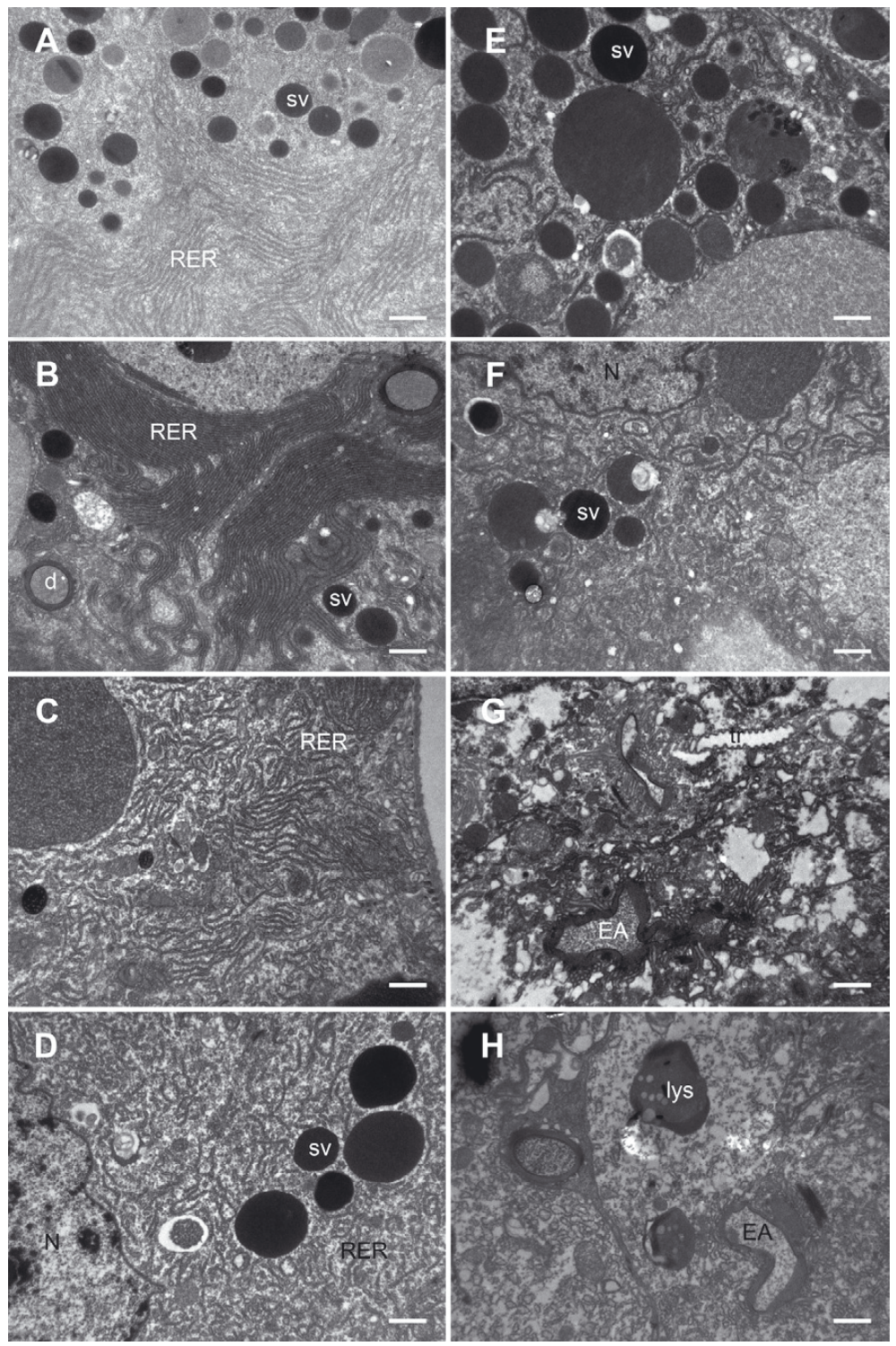

Figure 6. Electron micrographs of hypopharyngeal gland cytoplasm (scale bar $1 \mu \mathrm{m}$ ). Left column: control bee gland cells, using the same time series as in Figure 5, (A-D). Right column: Fenoxycarb-treated gland cells $(\mathrm{E}-\mathrm{H})$, same time series as in the controls. Inside the control gland cells we clearly see many electrondense vesicles (A) and RER forming pack layers (B) during the peak moments of secretion. Over time, the RER becomes less organized (C). However, secretion still continues at day 14 (D) yielding fewer, more electron-dense vesicles. In the treated glands we already see this unorganized cytoplasm at day 8 (E). Already the last vesicles form at day $10(\mathrm{~F})$ but hardly any RER is left. At day 12 and $14(\mathrm{G}$ and $\mathrm{H})$, no more secretion occurs and lysozomes roam the cells to break down the debris. Used symbols: d: duct cell; EA: end apparatus; lys: lysozome; N: nucleus; RER: granular endoplasmatic reticulum; sv: secretory vesicles; tr: tracheole. 
Imidacloprid- and Indoxacarb-treated bees. Although it is striking that both Imidacloprid and Indoxacarb displayed a similar histological pattern of many small dense vesicles, ultrastructural gland cell morphology did not reveal any obvious differences with the Captan-treated or control bees.

We have a whole other story when Fenoxycarb-treated bees are considered. It seems that this JH-mimic, unlike the other tested products, has a much more profound effect on the honeybee's hypopharyngeal gland.

While Malone et al. (2004) found that hypopharyngeal glands were unaffected by a number of insecticidal transgene products like $\mathrm{Bt}$ toxin and aprotinin, a biotin-binding protein, Rutz et al. found already in 1974 that JH mimics cause premature degeneration of the hypopharyngeal glands.

Degeneration of these glands normally accompanies a worker's shift from nest to field activities (Robinson and Ratnieks, 1987) and Simpson et al. (1968) stated that the size of the glands in foragers corresponds with that of the still undeveloped gland of newly emerged bees.

In 2005, Deseyn and Billen performed an in-depth analysis of the histology and ultrastructure of the honeybee hypopharyngeal gland, describing a flexible secretory activity in relation to the needs for feeding brood. Glands from young bees secrete royal jelly while older bees have more enzyme-rich secretions and gradually display degenerative structures in their gland cells (Ohashi et al., 1997). These degenerative structures are suggested to be segrozomes (Cruz-Landim and Hadek, 1969), which are a kind of lysozomes. Silva de Moraes and Bowen (2000) reported apoptosis, necrosis and a vacuolar form of programmed cell death in forager bees where the latter form of cell death was accompanied by an enhanced level of autophagic and hydrolytic activity, predominately in older foraging bees, in which a cytosolic source of acid phosphatase became manifest. Finally, in a 2004 study, Furquim et al. found that using an artificial high energy diet like nectar, cell death in the glandular tissue was more pronounced.

In our measurements on Fenoxycarbtreated bees, the glands' acini showed malfor- mations in size and shape far more quickly than normal, indicating disintegration early in life. Treated glands already had a granular texture from day 8 , occurring in control bees only from day 14 . The cytoplasm soon appeared unorganized and distinction between different structures and organelles became more difficult very rapidly. The cells started to merge and lysozomes appeared, as described in Deseyn and Billen (2005) for 21 day old untreated bees. These results fit into the paradigm that Fenoxycarb acts as an inducer of precocious foraging (Thompson et al., 2007; Heylen et al., unpubl. data).

\section{ACKNOWLEDGEMENTS}

We thank Dr. T. Wenseleers, A. Vandoren, S. Bers and E. Willems for expert technical assistance. This work was supported by grants from The Institute for the promotion of Innovation by Science and Technology in Flanders (IWT 040669) and by FWO grant G.517.05N.

Effets de quatre produits phytosanitaires sur la morphologie et l'ultrastructure de la glande hypopharyngienne de l'abeille, Apis mellifera.

produit phytosanitaire / glande hypopharyngienne / abeille / histologie

Zusammenfassung - Der Effekt von vier Pflanzenschutzmitteln auf die Morphologie und die Ultrastruktur der Hypopharynxdrüse der westlichen Honigbiene, Apis mellifera. Ziel dieser Untersuchung war es, den Einfluss von subletalen Dosen von Pflanzenschutzmitteln auf die Größe und Morphologie der Hypopharynxdrüse bei Honigbienen aufzuklären. Dazu wurden vier häufig im Obstanbau eingesetzte Produkte verwendet: Captan, Imidacloprid, Fenoxycarb und Indoxacarb. Der Grund für die Untersuchung der Hypopharynxdrüse ist die Sekretion von Gelée Royale, das vor allem von jungen Arbeiterinnen bereitgestellt wird und die Hauptnahrung der Bienenlarven darstellt. Eine Abnahme der Drüsenaktivität und damit eine Reduzierung der Futtersaftproduktion würden die Brutpflege und das Wachstum des Bienenvolkes beeinträchtigen. Da einige Untersuchungen darauf hinweisen, dass bestimmte Insekten-Wachstumsregulatoren wie Fenoxycarb eine Unterentwicklung der Hypopharynxdrüse verursachen können, haben wir dieses wichtige Insektizid bewusst mit einbezogen. In sechs 
Experimenten erhielten die 7 Tage alten Kontrollbienen ausschließlich Zuckerwasser und Placebobehandlungen, während die gleich alten Testbienen jeweils mit einem der vier Pestizide behandelt wurden und im Alter von 8 bzw. 14 Tagen (also 1 Tag bzw. 1 Woche nach der Behandlung) analysiert wurden. Bei den Kontrollbienen und den mit Fenoxycarb behandelten Bienen wurden mehr Analysen, nämlich im Alter von 8, 9, 10, 11, 12 und 14 Tagen durchgeführt. Bei unseren Kontrollbienen konnten wir bestätigen, dass die Durchmesser der Drüsen-Acini mit zunehmendem Alter abnahmen. Bei den 14 Tage alten Bienen waren zusätzlich die Acini aller mit Pestiziden behandelten Bienen kleiner als bei den Kontrollbienen, wobei nur die Unterschiede für Fenoxycarb und Imidacloprid signifikant waren (Abb. 1, Tab. I). In licht- und elektronenmikroskopischen Bildern konnten kaum Unterschiede bei den Drüsenzellen von Kontrollbienen und mit Captan, Imidacloprid oder Indoxacarb behandelten Bienen festgestellt werden (Abb. 2 und 3). Nach Fenoxycarb-Behandlung zeigten die Acini allerdings rascher Missbildungen in Größe und Form als unter normalen Bedingungen, was auf $\mathrm{Ab}-$ bauprozesse in frühen Lebensphasen hinweist. Behandelte Drüsen hatten bereits eine granuläre Struktur am Tag 8, während diese bei Kontrollbienen erst vom 14. Tag an auftraten. Das Zytoplasma erschien rasch unorganisiert und eine Unterscheidung zwischen unterschiedlichen Strukturen und Organellen wurde ebenfalls schwieriger. Die Zellen begannen zu verschmelzen und es tauchten Lysozyme auf wie sie von Deseyn und Billen (2005) bei unbehandelten Bienen erst im Alter von 21 Tagen beschrieben wurden (Abbs. 5 and 6).

Wir nehmen an, dass eindeutige Effekte auf den Durchmesser der Acini und auf die gesamte Drüsenhistologie auch Auswirkungen auf die Fitness des Bienenvolkes haben. Bei Bienen, die mit Captan, Imidacloprid und Indoxacarb behandelt wurden, sind die Unterschiede zu den Kontrollen allerdings zu gering um irgendwelche Schlussfolgerungen zu ziehen. Für diese Produkte sind weitere Untersuchungen notwendig. Der JH-analoge Wirkstoff Fenoxycarb scheint dagegen deutlich mehr Effekte auf die Hypopharynxdrüsen von Honigbienen zu haben. Da eine Rückentwicklung dieser Drüse normalerweise mit dem Wechsel von Stockarbeiten zur Sammeltätigkeit einhergeht, bestätigen unsere Ergebnisse die Annahme, dass Fenoxycarb als Auslöser für vorgezogene Sammeltätigkeit fungiert.

\section{Pflanzenschutzmittel / Hypopharynxdrüse /} Honigbiene / Histologie

\section{REFERENCES}

Bortolotti L., Montanari R., Marcelino J., Medrzycki P., Maini S., Porrini C. (2003) Effects of sub-lethal imidacloprid doses on the homing rate and foraging activity of honey bees, Bull. Insectology 56, 63-67.

Buckingham S.D., Lapied B., Le Corronc H., Grolleau F., Sattelle D.B. (1997) Imidacloprid actions on insect neuronal acetylcholine receptors, J. Exp. Biol. 200, 2685-2692.

Chauzat M.P., Faucon J.P., Martel A.C., Lachaize J., Cougoule N., Aubert M. (2006). Survey of Pesticide Residues in Pollen Loads Collected by Honey Bees in France, J. Econ. Entomol. 99, 253262.

Cruz Landim C. da, Hadek R. (1969) Ultrastructure of Apis mellifera hypopharyngeal gland, Proc. 6th Int. Congr. IUSSI, Bern, pp. 121-130.

Decourtye A., Armengaud C., Renou M., Devillers J., Cluzeau S., Gauthier M., Delegue M.H.P. (2004) Imidacloprid impairs memory and brain metabolism in the honeybee (Apis mellifera L.), Pest. Biochem. Physiol. 78, 83-92.

Deseyn J., Billen J. (2005) Age-dependent morphology and ultrastructure of the hypopharyngeal gland of Apis mellifera workers (Hymenoptera, Apidae), Apidologie 36, 49-57.

Dhadialla T.S., Carlson G.R., Le D.P. (1998) New insecticides with ecdysteroidal and juvenile hormone activity, Annu. Rev. Entomol. 43, 545-569.

El Hassani A.K., Dacher M., Gary V., Lambin M., Gauthier M., Armengaud C. (2008) Effects of sublethal doses of acetamiprid and thiamethoxam on the behavior of the honeybee (Apis mellifera), Arch. Environ. Contam. Toxicol. 54, 653-661.

Faucon J.-P., Mathieu L., Ribiere M., Martel A.-C., Drajnudel P., Zeggane S., Aurieres C., Aubert M.F.A. (2002) Honey bee winter mortality in France in 1999 and 2000, Bee World 83, 14-23.

Furquim K.C.S., Camargo-Mathias M.I., Silva de Moraes R.L.M. (2004) Morphological modifications induced by an artificial diet on the hypopharyngeal glands of Apis mellifera (Hymenoptera, Apidae) during their degenerative process, Sociobiology 43, 45-49.

Haynes K.F. (1988) Sublethal effects of neurotoxic insecticides on insect behavior, Annu. Rev. Entomol. 33, 149-168.

Hrassnigg N., Crailsheim K. (1998) Adaptation of hypopharyngeal gland development to the brood status of honeybee (Apis mellifera L.) colonies, J. Insect Physiol. 44, 929-939.

Lapied B., Grolleau F., Sattelle D.B. (2001) Indoxacarb, an oxadiazine insecticide, blocks insect neuronal sodium channels, Br. J. Pharmacol. 132, 587-595.

Malone L.A., Todd J.H., Burgess E.P.J., Christeller J.T. (2004) Development of hypopharyngeal glands in adult honey bees fed with a Bt toxin, a biotin binding protein and a protease inhibitor, Apidologie 35, 655-664. 
Medrzycki P., Montanari R., Bortolotti L., Sabatini A.G., Maini S., Porrini V. (2003) Effects of Imidacloprid administered in sub-lethal doses on honey bee behaviour. Lab tests, Bull. Insectology 56, 59-62.

Ohashi K., Natori S., Kubo T. (1997) Change in the mode of gene expression of the hypopharyngeal gland cells with an age-dependent role change of the worker honeybee Apis mellifera L., Eur. J. Biochem. 249, 797-802.

Owens R.G. (1969) Metabolism of fungicides and related compounds, Ann. N.Y. Acad. Sci. 160, 114 132.

Robinson G.E., Ratnieks F.L.W. (1987) Induction of premature honey bee (Hymenoptera: Apidae) flight by juvenile hormone analogs administered orally or topically, J. Econ. Entomol. 80, 784-787.

Rutz W., Gerig L., Wille H., Lüscher M. (1974) A bioassay for juvenile hormone $(\mathrm{JH})$ effects of insect growth regulators (IGR) on adult worker honeybees, Bull. Soc. Entomol. Suisse 47, 307-313.

Sasagawa H., Sasaki M., Okada I. (1989) Hormonal control of the division of labor in adult honeybees (Apis mellifera L.). I. Effect of methoprene on corpora allata and hypopharyngeal gland, and its $\alpha$-glucosidase activity, Appl. Entomol. Zool. 24, 66-77.

Silva de Moraes R.L.M., Bowen I.D. (2000) Modes of cell death in hypopharyngeal glands of honey bee (Apis mellifera L.), Cell Biol. Int. 24, 737-743.
Simpson J., Riedel I.B.M., Wilding N. (1968) Invertase in the hypopharyngeal glands of the honeybee, $\mathrm{J}$. Apic. Res. 7, 29-36.

Suchail S., Guez D., Belzunces L.P. (2001) Discrepancy between acute and chronic toxicity induced by imidacloprid and its metabolites in Apis mellifera, Environ. Toxicol. Chem. 20, 2482-2486.

Tasei J.N. (2001) Effects of insect growth regulators on honey bees and non-Apis bees. A review, Apidologie 32, 527-545.

Thompson H.M., Wilkins S., Battersby A.H., Waite R.J., Wilkinson D. (2005) The effects of four insect growth-regulating (IGR) insecticides on honeybee (Apis mellifera L.) colony development, queen rearing and drone sperm production, Ecotoxicology 14, 757-769.

Thompson H.M., Wilkins S., Battersby A., Waite R.J., Wilkinson D. (2007) Modelling long-term effects of IGRs on honey bee colonies, Pest Manage. Sci. 63, 1081-1084.

Tsurubuchi Y., Kono Y. (2003) Modulation of sodium channels by the oxadiazine insecticide indoxacarb and its N-decarbomethoxylated metabolite in rat dorsal root ganglion neurons, Pest Manage. Sci. 59, 999-1006.

van der Steen J. (2001) Review of the methods to determine the hazard and toxicity of pesticides to bumblebees, Apidologie 32, 399-406. 